\title{
Community Satisfaction of User Health Care Analysis at RSUD Kajen, Pekalongan Regency
}

\author{
Susi Sulandari \\ \{sulandari_susi@yahoo.co.id\} \\ Universitas Diponegoro, Indonesia
}

\begin{abstract}
Public services can be interpreted as providing services (serving) the needs of the people or communities who have an interest in the Organization in accordance with the basic rules and ordinances that have been established. Kajen District Public Hospital (RSUD) as a hospital belonging to the local government of Pekalongan, is the largest hospital and is a reference for the people of Pekalongan regency. According to the demands and progress of society, Kajen Hospital is required to be able to provide good health services. Good health services are expected to provide satisfaction to the patient. To find out the level of public satisfaction to the service provided by Kajen Hospital of Pekalongan District, it is necessary to do a measurement of the level of public satisfaction on health services received. The level of satisfaction is the difference between service performance and service expectations that the community wants. The purpose of this research is to measure public satisfaction on health services provided by Kajen Hospital of Pekalongan Regency. The methods used in this study use a descriptive quantitative approach. Total populations 59.379. The results of the study show the value of public satisfaction on the service provided by Kajen Hospital is quite satisfied. The suggestion that given are: improvement in the speed of completion time in providing as well as repair of facilities and infrastructures such as comfortable and clean waiting room.
\end{abstract}

Keywords: Service, Satisfaction.

\section{Introduction}

Public services can be interpreted as providing services (serving) the needs of people or communities who have an interest in the organization in accordance with the basic rules and procedures that have been determined [1]. Kajen Regional General Hospital (RSUD), as a hospital-owned by the Regional Government of Pekalongan Regency is the largest hospital and it has become a reference hospital for the people of Pekalongan Regency. In accordance with the demands and progress of the community, Kajen Regional Hospital is demanded to be able to provide good health services [2]. Good health services are expected to provide satisfaction to patients [3]. Based on the Community Satisfaction Survey (SKM) in 2018, that conducted by Kajen Regional Hospital, it showed suboptimal results. The score obtained is 76.51 with a good category. This score should be increased to an excellent level. There are some service elements that get a poor evaluation, so it needed to get attention. The elements that get low scores are the clarity of service standards and the suitability of service standards. Based on it, this research was conducted to assess the level of community satisfaction who use the health services in Kajen District Hospital, Pekalongan Regency. This research will analyze 
the performance of health services in the Kajen Regional General Hospital, Pekalongan Regency, the expectation and the satisfaction level of people who use health services at the Kajen Regional General Hospital, Pekalongan Regency.

\section{Research Method}

This research used a descriptive quantitative approach, which is to describe and analyze [4] the performance of health services and the expectations of community health service users and the level of community satisfaction of users of health services in the Kajen Regional General Hospital, Pekalongan Regency. The population of this study was all the people who use outpatient health services (59.379) in Kajen Regional Hospital, Pekalongan Regency, while the sample was 100 people taken by accidentally methods and using the Slovin formula [5]. Respondents were drawn from (5) five polyclinics. Five polyclinics will be selected by those who have the biggest patients in 2018, those were internal, child, uterine, neurological and Nose and Throat ear clinics. And for additional information is needed from hospital management. Research on the Analysis of Satisfaction of Health Service Users in Kajen District Hospital, Pekalongan Regency, focuses on the satisfaction of Health Service Users. the location of this study was the Kajen District Hospital in Pekalongan District outpatient unit. This research used Primary data, it was data that obtained /taken directly from the source (research subjects) [6] that is the Public Health Service Users in Kajen District Hospital. Secondary data was data obtained from library materials that were relevant to the problem under study. The form of secondary data used by the researcher were notes, books, literature, newspapers, documents, reports, and other sources related to research. The data collection of this research [7] used observation, interviews, literature studies, and documentation techniques. Data Analysis Techniques used in this research was quantitative analysis using averages, comparison of average performance and expectations (\%) and Cartesian Diagrams [5]. The indicators for service user satisfaction include [8]: Compliance with service requirements with the type of service, ease of service mechanisms and procedures, speed of completion time in providing services, reasonableness of costs/tariffs in services, appropriateness of service products between those listed in service standards with the results provided, competence or ability of officers in service, behavior of officers in service related to politeness, behavior of officers in services related to hospitality, behavior of officers in services related to discipline, quality of facilities and infrastructure, environmental comfort, Security of service, service justice (queue), timeliness of service.

\section{Result and Discussion}

The results of health services performance research in the Kajen Regional General Hospital, Pekalongan District obtained an average number of 2.95, it shows that the performance of health services in the Kajen Regional General Hospital, Pekalongan Regency is in good category [8], it is proven by all of its good indicators although there are some indicators still positioning in low intervals such as ease of service mechanisms and procedures, speed of completion time in providing services, behavior of officers in service related to discipline, quality of facilities and infrastructure, environmental comfort, and timeliness of services which get an average of less than three. Whereas the expectation of 
people who use health services at the Kajen Regional General Hospital, Pekalongan Regency is obtained an average of 3.14, which means that the expectations of people who use health services at the Kajen Regional General Hospital, Pekalongan Regency want better than their performance. From the performance and expectations of people who use health services at the Kajen Regional General Hospital, Pekalongan Regency, the satisfaction level is $91.55 \%$, which means that the public health service users at the Kajen Regional General Hospital, Pekalongan Regency are still quite satisfied with the services provided. For more details can be seen in the following table:

Table 1. Average Performance Appraisal and Expectations of Service Users at Kajen District General Hospital in Pekalongan Regency in 2019

\begin{tabular}{|c|c|c|c|c|c|c|c|c|}
\hline No & Service Elements & $\begin{array}{l}\text { Assessment } \\
\text { Performance } \\
\text { (X) }\end{array}$ & $\begin{array}{l}\text { Assessment } \\
\text { Expectation } \\
\text { s (Y) }\end{array}$ & $\begin{array}{l}\text { Average } \\
\text { (X) }\end{array}$ & $\begin{array}{l}\text { Average } \\
\text { (Y) }\end{array}$ & $\begin{array}{c}\text { satisfaction } \\
\text { value }(\%) \\
(5) /(6) \% \\
100 \%\end{array}$ & $\begin{array}{c}\text { Satisfaction } \\
\text { Category }\end{array}$ & DK \\
\hline (1) & (2) & (3) & (4) & (5) & (6) & (7) & $(8)$ & $(9)$ \\
\hline 1 & $\begin{array}{l}\text { Conformity of } \\
\text { Service } \\
\text { Requirements with } \\
\text { the Type of Service }\end{array}$ & 303 & 315 & 3.03 & 3.15 & 96,19 & $\begin{array}{c}\text { quite } \\
\text { satisfied }\end{array}$ & $\mathrm{D}$ \\
\hline 2 & $\begin{array}{l}\text { Ease of Service } \\
\text { Mechanisms and } \\
\text { Procedures }\end{array}$ & 294 & 309 & 2.94 & 3.09 & 95,15 & $\begin{array}{c}\text { quite } \\
\text { satisfied }\end{array}$ & $\mathrm{C}$ \\
\hline 3 & $\begin{array}{l}\text { Speed of Settlement } \\
\text { Time in Providing } \\
\text { Services }\end{array}$ & 280 & 316 & 2.80 & 3.16 & 88,61 & $\begin{array}{c}\text { quite } \\
\text { satisfied }\end{array}$ & A \\
\hline 4 & $\begin{array}{l}\text { Reasonableness of } \\
\text { Cost / Tariff in } \\
\text { Services }\end{array}$ & 42 & 48 & 3.00 & 3.43 & 87,46 & $\begin{array}{c}\text { quite } \\
\text { satisfied }\end{array}$ & B \\
\hline 5 & $\begin{array}{l}\text { Conformity of } \\
\text { Service Products } \\
\text { between those listed } \\
\text { in Service } \\
\text { Standards and the } \\
\text { Results Delivered }\end{array}$ & 302 & 314 & 3.02 & 3.14 & 96,12 & $\begin{array}{c}\text { quite } \\
\text { satisfied }\end{array}$ & B \\
\hline 6 & $\begin{array}{l}\text { Staff Competencies } \\
\text { or Capabilities in } \\
\text { Service }\end{array}$ & 312 & 328 & 3.12 & 3.28 & 95,12 & $\begin{array}{c}\text { quite } \\
\text { satisfied }\end{array}$ & B \\
\hline 7 & $\begin{array}{l}\text { Behavior of } \\
\text { Officers in Services } \\
\text { related to Politeness }\end{array}$ & 309 & 316 & 3.09 & 3.16 & 97,78 & $\begin{array}{c}\text { quite } \\
\text { satisfied }\end{array}$ & B \\
\hline 8 & $\begin{array}{l}\text { The Behavior of } \\
\text { Officers in Services } \\
\text { is related to friendly }\end{array}$ & 302 & 322 & 3.02 & 3.22 & 93,79 & $\begin{array}{c}\text { quite } \\
\text { satisfied }\end{array}$ & B \\
\hline 9 & $\begin{array}{l}\text { Behavior of } \\
\text { Officers in Services } \\
\text { related to discipline }\end{array}$ & 289 & 309 & 2.89 & 3.09 & 93,53 & $\begin{array}{c}\text { quite } \\
\text { satisfied }\end{array}$ & $\mathrm{C}$ \\
\hline 10 & $\begin{array}{l}\text { Quality of Facilities } \\
\text { and Infrastructure }\end{array}$ & 272 & 302 & 2.72 & 3.02 & 90,07 & $\begin{array}{l}\text { quite } \\
\text { satisfied }\end{array}$ & $\mathrm{C}$ \\
\hline 11 & $\begin{array}{l}\text { Environmental } \\
\text { Comfort }\end{array}$ & 283 & 304 & 2.83 & 3.04 & 93,09 & $\begin{array}{l}\text { quite } \\
\text { satisfied }\end{array}$ & $\mathrm{C}$ \\
\hline 12 & Service Security & 295 & 304 & 2.95 & 3.04 & 97,04 & $\begin{array}{l}\text { quite } \\
\text { satisfied }\end{array}$ & $\mathrm{D}$ \\
\hline 13 & $\begin{array}{l}\text { Justice Services } \\
\text { (queues) }\end{array}$ & 314 & 323 & 3.14 & 3.23 & 97,21 & $\begin{array}{c}\text { quite } \\
\text { satisfied }\end{array}$ & B \\
\hline 14 & $\begin{array}{l}\text { Timeliness of } \\
\text { Service }\end{array}$ & 273 & 293 & 2.73 & 2.93 & 93,17 & $\begin{array}{c}\text { quite } \\
\text { satisfied }\end{array}$ & $\mathrm{C}$ \\
\hline
\end{tabular}




\begin{tabular}{|c|c|c|c|c|c|c|c|c|}
\hline No & Service Elements & $\begin{array}{c}\text { Assessment } \\
\text { Performance } \\
\text { (X) }\end{array}$ & $\begin{array}{c}\text { Assessment } \\
\text { Expectation } \\
\text { s (Y) }\end{array}$ & $\begin{array}{c}\text { Average } \\
\text { (X) }\end{array}$ & $\begin{array}{l}\text { Average } \\
\text { (Y) }\end{array}$ & $\begin{array}{c}\text { satisfaction } \\
\text { value }(\%) \\
(5) /(6) * \\
100 \% \\
\end{array}$ & $\begin{array}{c}\text { Satisfaction } \\
\text { Category }\end{array}$ & DK \\
\hline$(1)$ & $(2)$ & (3) & $(4)$ & $(5)$ & $(6)$ & $(7)$ & $(8)$ & $(9)$ \\
\hline & Average & & & 2,95 & 3,14 & 93,86 & & \\
\hline & Level of satisfaction & & & \multicolumn{5}{|c|}{$3,14 / 3,43 * 100 \%=91,55 \%$ (quite satisfied) } \\
\hline
\end{tabular}

Source: Processed field data

Note: DK: Position on the Cartesian Diagram

To see the suitability of the performance elements and the expectations of service users in the Kajen Regional General Hospital (Pakalongan District Hospital) [9], see the following Cartesian diagram:

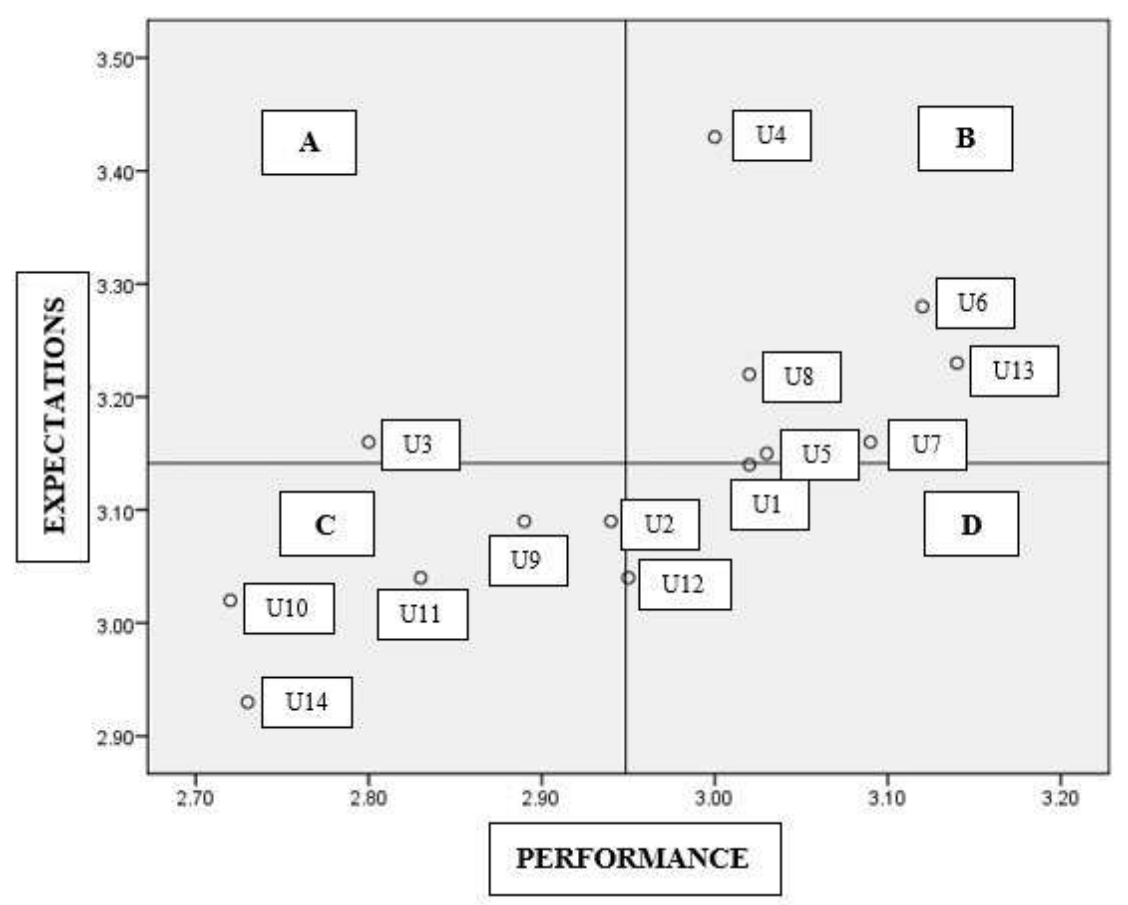

Fig. 1. Cartesian diagram of Average performance and expectations of service users on Regional General Hospital (RSUD) Kajen, Pekalongan Regency 2019 (Source: Processed field data).

From the results of research and data analysis through the Cartesian diagram above, it shows several things [10], those are:

a) Quadrant A

The element that is considered to be very important influences the satisfaction of service users at the Regional Public Hospital (RSUD) Kajen, Pekalongan Regency, but the performance of services has not been carried out in accordance with the wishes of service users, it is the speed of completion time in providing services. 
b) Quadrant B

The basic service elements that have been successfully implemented by the Regional General Hospital (RSUD) Kajen Pekalongan Regency and must be maintained because it is considered very important and very satisfying is the reasonableness of costs/tariffs in services, the suitability of service products between those listed in service standards and the results provided, competence or ability of officers in service, behavior of officers in services related to politeness, behavior of officers in services related to hospitality, and justice of services (queues).

c) Quadrant C

Less important elements of influence for service users and unsatisfactory are the ease of service mechanisms and procedures, the behavior of officers in service related to discipline, the quality of facilities and infrastructure, environmental comfort, and timeliness of service.

d) Quadrant D

The element that is considered less important for the community of users of Kajen Regional General Hospital (RSUD) in Pekalongan Regency but the service is very satisfying is the suitability of the service requirements with the type of service and service security.

\section{Conclusion}

The conclusion from this study is the performance of health services in the Kajen Regional General Hospital, Pekalongan District obtained an average number of 2.95 or the performance of health services in the Kajen Regional General Hospital, Pekalongan Regency can be said to be good. And for the expectations of people who use health services at the Kajen Regional General Hospital, Pekalongan Regency, an average figure of 3.14 is obtained, which means good, but the community wants it to be better than its performance. While the level of satisfaction is $91.55 \%$, which means that people who use health services in the Kajen District General Hospital, Pekalongan Regency are still not satisfied with the services provided. To increase the satisfaction of the community of health service users at Kajen District General Hospital, Pekalongan Regency, based on the results of the Cartesian diagram, it can be seen in quadrant A where the performance of community service users of health services at the Kajen Regional General Hospital, Pekalongan Regency is still considered low compared to community expectations health service users at the Kajen District General Hospital, Pekalongan Regency. The element that must be improved is the speed of completion time in providing services, namely by providing socialization on how to register online.

\section{References}

[1] A. Dwiyanto, Reformasi Pelayanan Publik. Jakarta: PT. Gramedia, 2003.

[2] A. S. Ratminto dan Winarsih, Manajemen Pelayanan. Yogyakarta: Pustaka Pelajar, 2006.

[3] P. Napittupulu, Pelayanan Publik dan Customer Satisfaction. Bandung: PT. Alumni, 2012.

[4] Sugiyono, Metode Penelitian Kuantitatif. Bandung: Alfabeta, 2018.

[5] Budiyono, Statistika untuk Penelitian. Surakarta: UNS Press, 2009.

[6] Sugiyono, Metode Penelitian Kuantitatif, Kualitatif, dan R\&D. Bandung: CV. Alfabeta, 2017.

[7] S. Arikutno, Prosedur Penelitian suatu Pendekatan Praktek. Yogyakarta: Rineka Cipta, 2002. 
[8] Hardiyansyah, Kualitas Pelayanan Publik Konsep, Dimensi, Indikator dan Implementasinya. Yogyakarta: Gava Media, 2011.

[9] A. Muhid, Analisis Statistik SPSS for Windows: Cara Praktis Melakukan Analisis Statistik. Surabaya: CV. Duta Aksara, 2010.

[10] S. Azwar, Reabilitas dan Validitas. Yogyakarta: Pustaka Pelajar, 2002. 